\section{On the Construction of Rule of Law Culture Centered on Harmonious Society}

\author{
Dong Bangjun* \\ Department of Criminology, Zhongnan University of Economics and Law, China
}

\begin{abstract}
Harmonious society is an important development goal of China and a concept of governing the country. The construction of the culture of rule of law in trinsically unite with the connotation of harmonious society; the culture of rule of law we want to construct not only has the commonality in the development of rule of law culture, but also has the nationality and regionality of China; the construction of the culture of rule of law should adhere to the rational thinking of combining history and reality, local and extra-territorial, transplantation and innovation, especially the promotion and popularization of the culture of rule of law.
\end{abstract}

Keywords: Connotation; Construction; Harmonious society; The culture of rule of law

\section{Introduction}

\section{Harmonious society and the culture of rule of law}

\section{The clear concept of the culture of rule of law}

The understanding of the concept of culture of rule of law needs to be carried out from the meaning of the legal culture. The American jurist Lawrence Friedman first proposed the concept of legal culture in the strict sense in the article "Legal Culture and Social Development". Since then, scholars and experts at home and abroad have different attitudes towards it. Some scholars believe that: "Legal culture refers to the concepts, values, expectations and attitudes of the legal and legal systems held by certain people or certain members of the public." Some scholars advocate that the legal culture should be understood in a broad sense. They believe that "legal culture is the sum of legal ideology, legal norms that are compatible with legal ideology, legal systems, legal organizations and legal facilities." Others believe

*Corresponding author: Dong Bangjun, Department of Criminology, Zhongnan University of Economics and Law, China. Tel: +86 13971328500; Email: 13971328500@139.com

Citation: Bangjun D (2019) On the Construction of Rule of Law Culture Centered on Harmonious Society. Forensic Leg Investig Sci 5: 031

Received: August 12, 2019; Accepted: August 15, 2019; Published: August 22, 2019

Copyright: ( 2019 Bangjun D. This is an open-access article distributed under the terms of the Creative Commons Attribution License, which permits unrestricted use, distribution, and reproduction in any medium, provided the original author and source are credited. that legal culture should be a position and method" applied cultural interpretation method to legal research." Due to the polysemy of the concept of culture, scholars have different opinions on the meaning of legal culture, but they can be divided into two types: the method of legal research and the entity with research objects. The latter can be divided into two kinds of viewpoints: the culture of the conceptual form, the culture of the conceptual form and substantial form. The emphasis of each viewpoint on the "concept" or "substance" is different.

The so-called culture of rule of law is often expressed as a legal culture in the legal world; in the political sciences, it is often expressed as a culture of rule of law. Legal culture is opposite of political culture and religious culture; the culture of rule of law is opposite to the culture of rule by individuals. The legal culture can involve the past, the present and the future; the culture of rule of law focuses on the modern form of legal culture. The concepts we generally use are the same and can be used in many ways. From the cultural perspective, the culture of rule of law can be divided into the one on the explicit structure and the other on the implicit structure. The culture of rule of law on the explicit structure can be divided into laws and regulations, legal systems and legal facilities. The culture of rule of law on the implicit structure can be divided into legal psychology, legal awareness (legal concept) and legal thinking. In theory, any kind of legal culture, no matter what it is in the content or in the structure, should be harmonized and unified on the explicit and implicit levels. That is the harmonization among the tangible legal norms, legal systems, legal facilities, and the intangible legal ideology which is compatible with the tangible structure [1].

However, there are differences between the culture of rule of law and the legal culture. First of all, from the perspective of historical development, legal culture is the condensation of history and reality, including the achievements of legal culture in the past and present. It is a comprehensive reflection of ancient, modern and contemporary legal thoughts, theories and concepts, while the culture of rule of law is the product of legal culture when it develops to a certain historical stage. The culture of rule of law is a concentrated reflection of modern and contemporary legal thoughts, theories and concepts, and is inseparable from the rise and development of modern democratic politics. Throughout the history of development of human society, the culture of rule of law is always closely linked to the ideals pursued by human beings such as law, rights, freedom, democracy, equality, and order. The legal culture can involve the past, the present and the future. The culture of rule of law focuses on the modern form of legal culture. Secondly, from the cultural basis, legal culture has no special requirements for culture, while the culture of rule of law emphasizes the need for rational culture as its cultural basis. The cultural foundations required by rule of law include the scientific spirit, human rights ideology, civic awareness, and rights concepts. Without these rational cultures, the culture of rule of law can be neither established nor maintained. Thirdly, from the perspective of concept, legal culture is the opposite of political culture, religious culture and etc. The culture of rule of law is the opposite of the culture of rule by individuals and 
culture of rule by rites. Since rule of law is by no means simply about the law, but a kind of legal governance established on the basis of negation of rule by individuals, rule of law and rule by individuals have very different ideological and theoretical foundations. Therefore, in this sense, the culture of rule of law is an important symbol in human society that presented rule by individuals changed into rule of law. It is the concentrated expression of the modernization of legal culture [2]. The culture of rule of law is the existence of the "spiritual" level which is the opposite to the "artifact" level. It is the concept of rational culture rather than irrational culture. It is a type of culture that is reflected in industrial society rather than agricultural society.

Therefore, the culture of rule of law is an intrinsic spiritual part of the legal phenomenon, which is distinguished from the external explicit elements such as the legal norm system, legal facilities, legal system operation. It mainly includes thoughts, consciousness, feelings, beliefs, knowledge and theory on the current law. And so on. There are three levels in summary: [3] one is the level of legal psychology, which is mainly manifested as a psychological feeling and psychological reaction as well as a long-formed habits and customs, in general, whether it is willing or not to let the law adjust or standardize our daily life, for example, whether it despises the law, stays away from the law, or attaches importance to law and closeness to the law. The second is the level of legal awareness. Because consciousness is a complex, legal consciousness can only be a vague concept that includes mainly under the certain social conditions people's understanding, evaluation and emotional experience of the legal and legal phenomena of the current law, and adjustment of their own behaviors, and the resulting concept of rule of law such as the rights-based, legal supremacy. The third is the level of legal thought. The legal ideology is a high-level legal cognition. It is the sum total of the legalization and rationalization of legal and legal phenomena, and systematic legal consciousness and legal values. This level should reflect the supremacy of legal authority and rule of just law.

In summary, the author believes that the culture of rule of law is derived from a certain political, economic and cultural history and realistic environment, and has been relatively, stably accumulated in a country or region after a long-term socialization process, that is, the way of thinking and behaving of a country, region, nation and society towards legal life, which holds the values as the core, including people's awareness of rule of law, the concept of rule of law, the thinking of rule of law and the value towards legal.

Organic integration of the culture of rule of law and harmonious society

Harmonious society has profound connotation and can be expressed as "a stable, democratic and vigorous socialism society, where people can live harmoniously with the nature and friendly with each other, a rational social order and legal system can be established and fairness and justice can be upheld". Building a socialism culture of rule of law and establishing a harmonious society are inherently integrated.

First of all, the construction of harmonious society strongly promotes the culture of rule of law.

Mainly presenting in the following aspects:

i. The harmonious society itself is the value pursuit of the culture of rule of law. Harmonious society is not only a beautiful vision of our ideal society, but also a realistic goal of building a well-off society in an all-round way in the primary stage of socialism. Not only the concept of harmonious society constitutes the overall value orientation of the culture of rule of law in China, but also the six elements of the harmonious social connotation will become an important focus of the value of legal culture and value criterion in China.

ii. The construction of harmonious society creates an ecological environment for the culture of rule of law. The formation of the culture of rule of law depends on a certain social and historical background and specific conditions for formation. Since the reform and opening up, the gradual establishment of China's market economic system, the orderly advancement of democratic politics and the obvious progress of rational culture have laid a good background for the formation of the culture of rule of law in China. The proposal and development of harmonious society will further promote the coordinated development of China's material, political and spiritual civilizations, and will certainly create more favorable conditions for the formation of the culture of rule of law in China.

iii. The practice of harmonious society provides a broad platform for the construction of the culture of rule of law. The construction of harmonious society is not only an important value goal, but also a profound social practice. This practical process not only tests and enriches the theory of socialism with Chinese characteristics, but also provides a broad platform for the culture of rule of law in China. This platform not only can let the culture of rule of law with Chinese characteristics fully play its role, but will also let the culture of rule of law with Chinese characteristics continue to withstand the test of harmonious social practice and promote its continuous development.

Secondly, the construction of the culture of rule of law responds positively to harmonious society.

This can be explained from the following dimensions:

i. The culture of rule of law constitutes the soul and essence of the construction of harmonious society. The harmonious development of social modernization requires not only the material basis, but also the power of spiritual culture as its soul. The culture of rule of law as the advanced human culture must become an organic part of the soul of harmonious society and become an important spiritual orientation of socialism harmonious society. This point can be confirmed through putting democracy and rule of law in the first place of the connotation of harmonious society, and the fact that the spirit of the culture of rule of law is contained in every element.

ii. The rule of law culture provides effective institutional support for the construction of harmonious society. The culture of rule of law not only constitutes the soul of harmonious society as spiritual consciousness, but also served as a normative institutional form, that is, a good institutional arrangement, is more fundamental, overall, stable and long-term. It will provide a long-term system for harmonious society. It can be said that every aspect of the six aspects of the socialism harmonious society requires good institutional arrangements, and all need to be included in the rule of law to make it develop in a harmonious and orderly manner. 
iii. The culture of rule of law is the necessary way to reshape the legal quality of subjects in harmonious society. The culture of rule of law is not only expressed as the spiritual concept and normative system of the society, but also transforms and internalizes this concept and system into the value beliefs and behaviors of the social subject, and makes this concept and system become the legal quality of the subject. Since culture is a trait of human society, people are not only the creators and communicators of culture, but also the doers and carriers of culture. Therefore, in a unified social subject, culture embraces the quality of people, and quality reflects human culture; and because all aspects of social modernization will ultimately depend on the modernization of people's own qualities, it can be said that the modern citizen's legal quality conserved and shaped by the culture of rule of law will be a fundamental decisive factor in ensuring the success of China's social legal system modernization and harmonious society [4].

In this way, harmonious society and the culture of rule of law are closely related, mutually reinforcing. The two are unified in the great cause of building and developing socialism with Chinese characteristics, and unified in the grand plan of the great rejuvenation of the Chinese nation. We should also carefully consider the connotation of the construction of the culture of rule of law from the perspective of harmonious society.

\section{The Interpretation of the Connotation of the Culture of Rule of Law}

The academic community agrees that the culture of rule of law is the product of legal culture development in the modern stage. The culture of rule of law is based on the prosperity of commodity economy, developed democracy and civil society, and takes rights, freedom, equality, fairness, justice and rationality as essential elements, make sovereignty in the people, supreme authority of constitution and law, the protection of human rights, the supervision and control of public power, the administration of law and the fair and independent judiciary as core values, and includes a stable legal psychology in society such as compliance with the law, believing in law, law-protection. The interpretation of the connotation of the culture of rule of law can follow the following two ways of thinking.

\section{The advanced nature of the times}

The culture of rule of law is a way of thinking and behavior taking values as its core towards legal life which a country or a nation holds. In history, rule of law has always been linked to democracy. The fundamental spirit of rule of law is that the people are the masters of the country; the fundamental strength of rule of law lies in the support of the people; the core value of rule of law lies in the democratic system. Socialism democracy is people's democracy. The people's basic right to participate in the management of the country's social affairs through the election of representatives must be guaranteed. This basic right must and only under the leadership of the party can be realized. The people's democracy under the leadership of the Party is the political premise and political guarantee of the socialism rule of law. Therefore, the basic connotation of rule of law culture that we advocate is the people's democracy under the leadership of the Party and the high degree of condensation of the people's democratic spirit. The culture of rule of law with the people's democracy as its connotation reflects the concept of equality of the subject, the concept of honesty and the supremacy of law in terms of values, and reflects freedom, equality and human rights in the concept of consciousness. This content and form relationship of the people's democracy and the culture of rule of law reflects the class interests and democratic characteristics of advanced culture.

\section{Historical necessity}

With the continuous deepening of reforms, China has not only made great achievements in the economic field, but also the entire society has experienced tremendous changes. The people's material and cultural living standards have rapidly increased. In the past 40 years, people's thoughts, concepts, and understandings have greatly changed which particularly have direct, obvious, and strong reflection in their legal aspects. The performance is that with the expansion of the market economy's breadth and depth, laws and regulations that is appropriate with the development of market. At present, a relatively complete legal system has been formed. As a means of regulating market economic activities, the function of law has become increasingly prominent. The citizens' demands for the law and the consciousness using laws to protect their various rights and interests are constantly increasing. The rational expectations of using law to restrain, control, and crack down abuses of power are becoming more and more intense, and there are more and more examples that various social conflicts resolved through legal proceedings. This kind of change from concept and thought to system and behavior, which caused by the development of market economy, profoundly reflects the rapid development of the culture of rule of law of market economy in China, and also strongly illustrates that the market economy must construct a kind of the culture system of rule of law which is compatible with the development of itself. Therefore, the development of China's market economy forms the most direct and fundamental need for the culture of rule of law.

\section{Support of institution}

The socialism rule of law is an objective requirement and guarantee for promoting the healthy and stable development of socialism democratic politics. Socialism democracy is the inherent requirement of socialism and an important part of the fundamental rights and interests of the overwhelming majority of the Chinese people. Without rule of law, it means the arrival of anarchy. Only by institutionalizing democracy can we guarantee the authority and stability of democracy and ensure that the political life of the country operates in accordance with legal procedures; only under the guidance, norm and constraint of the law can citizens be rationalized and ordered in political participation, and ensure the effective operation of democratic procedures; only by using legal means to define the rights and obligations of various social subjects can we truly guarantee the realization of people's democratic rights. Therefore, democracy means rule of law, and democratic politics requires the culture of rule of law. In addition, the socialism rule of law is also an objective requirement for achieving social stability and long-term stability of the country. At the same time of China's rapid socio-economic development, there are many unfavorable factors that affect stability of order and social harmony. The culture of socialism rule of law should also have the connotation of the positive solution to these factors.

\section{International openness}

The socialism culture of rule of law is modern and open. Its modernity is manifested in its ability to accompany the contemporary 
market economy, democratic politics and spiritual civilization construction, and is an important part of the contemporary Chinese modernization movement. Its openness is manifested in that it has never let itself fall into the comfort zone, and is good at absorbing human beneficial legal and cultural achievements, especially transplanting and referring Western "rule of law" ideas and theories and Western legal systems, and communicating and responding in the education of Chinese and Western law. With the arrival of the era of economic globalization and the emergence of legal convergence, socialism legal culture and Western legal culture will coexist, and the entire human society is developing in the direction of harmonious rule of law.

\section{National locality}

The socialism culture of rule of law is an extremely important component in the construction and development of the socialism cause with Chinese characteristics. Its spiritual connotation should be deeply rooted in the rich soil of the Chinese nation. It is consistent with the cause of socialism construction and can reflect China's national conditions and national characteristics. Mr. Cai Shuheng believes that: Law is the form of state social organization, in the future, the construction of China's legal culture should be based on the national consciousness of law [5]. You can foresee that the culture of rule of law we want to build is neither continental nor British-American. It should be a socialism culture of rule of law with Chinese national characteristics. The basic connotation is the people's democracy under the leadership of the Party, and is the condensation of the people's democratic spirit. It is the culture of rule of law that is vividly interpreted by the reality and ideals of rule of law in China, rather than purely using the culture of the West or other developed countries to improve the life of the Chinese people.

\section{The Construction of Culture of Rule of Law in China}

In the new era, guided by the fundamental idea of building a harmonious society, the construction of the culture of rule of law in China should firmly base on the reality of China's social and economic development, and continue to adhere to the world's perspective, and focus on the continuous innovation of legal theory, gradually construct a socialism culture of rule of law with Chinese characteristics.

\section{The basic dimensions of the construction of the culture of rule of law}

\section{Dimension 1: The persistence of the national spirit}

Building the culture of rule of law must be based on the promotion of national spirit. The culture of the rule of law is a new form of modernization of China's excellent traditional culture [6]. Historically, different civilizations have produced legal and cultural traditions with different characteristics and different styles in their evolution. They constitute the carrier of national spirit, embody the national value norms and value pursuits, and contain the rich experience of national law adjustment, and also become a mirror for the national observation and reflection. China's legal culture is an important part of the advanced culture of socialism with Chinese characteristics, the fruit of the progress of social civilization, and the ideological and cultural foundation and spiritual drive to promote China's legal system. It is deeply rooted in the fertile soil of China, condenses the essence of national culture, has a unique spiritual character, formal characteristics and strong vitality, and is a concentrated expression of the national spirit. In the great process of building a well-off society in an allround way and accelerating socialism modernization, the cultivation and promotion of this cultural spirit is an important foundation for governing the country according to law [7]. The problem of today's construction of culture of rule of law should be how to effectively use local culture and ethical resources to serve the modernization of rule of law. Taking traditional Chinese culture and ethics as an example, the concept of tolerance contained in the "Doctrine of the Mean", and the integrity contained in "Good intention and friendly attitude", and the requirements of "People-oriented" idea for rule of law, the requirement of "Great harmony" contained for the rational order of rule of law, and the mechanism for reducing disputes reached by "Peace is most precious", all of these can become an effective local resource for the construction of the culture of rule of law [8]. Therefore, in the construction of the culture of rule of law, we must base on the traditional Chinese legal culture, inherit and carry forward the outstanding achievements of Chinese traditional culture, and maintain the nationality of the culture of rule of law.

\section{Dimension 2: Persistence of open attitude}

To build a culture of rule of law, we must maintain an open attitude. With the development of the trend of world economic integration, the integration of world culture is also carried out in a subtle manner. The excellent concept of rule of law in the West collides with and integrates with China's long history and culture, which is of great significance to the promotion of the construction of rule of law, the spirit of rule of law and the practice of rule of law in China. Every country has its own characteristics. The right way to treat Western culture is to absorb its essence and discard its dross. Some developed countries in the West have a long and developed legal process and have led the process of modernizing rule of law in the world and accumulated a large number of outstanding legal and cultural achievements. In development, we must learn from and absorb these outstanding achievements, and transform them into a legal culture that adapts to China's national conditions and promote the building of the culture of rule of law in China. Since the reform and opening up, we have paid attention to absorbing the excellent and beneficial legal and cultural achievements of the West, especially borrowing and transplanting Western theories of rule of law, the legal system and the educational way of rule of law, and effectively applied them to the construction of the culture of rule of law, and achieved remarkable results. The effect is particularly prominent in the areas of civil and commercial, economic and environmental. The openness and internationalization of the culture of rule of law should be guided by the concept of "harmony without uniformity", should be based on mutual respect and understanding, seeking common ground while reserving differences, in order to achieve the common progress in the construction of the culture of rule of law. This absorption and reference are not as same as the full westernization of the modernization of rule of law. Our country has different historical traditions and social systems from Western society. If the western legal culture is completely copied, it will inevitably lead to the superstructure being incompatible with the whole society, which will cause the malformation of the rule of law in China. Therefore, the essence of the open attitude in the construction of the culture of rule of law is reforging the civilization of rule of law in the West with Chinese characteristics, rather than mechanically splicing. 


\section{Dimension 3: The ultimate pursuit of legal modernization}

Modernizing the law must be the ultimate pursuit of building the culture of rule of law. China's culture of rule of law has a close relationship with the socialism market economy with Chinese characteristics. The competition of the comprehensive national strength of the world today has become a focus of global attention. Culture and politics are blended, and the role and status of them in competition are becoming more and more prominent. For China, which is developing at a rapid pace, the modernization of the economy will inevitably require the modernization of the superstructure to adapt to it, and the construction of rule of law plays a pivotal role in it. The market economy needs the culture of rule of law to maintain it. At the same time, the culture of rule of law is constantly improving and developing in the process of maintaining and adapting, thus promoting the birth of a new culture of legal administration. The culture of rule of law should continue to carry out theoretical innovation on the principle of market economy, and apply this new theoretical method to the development and operation of the market economy to promote the rapid development of the modern economy. Building a country ruled by law requires constantly updating the legal values. Because correct and good legal values can provide a correct direction and guidelines for enacting laws, strict enforcement, and correcting evil laws. The culture of rule of law plays an important role in the establishment of legal theory and the operation of legal practice, and provides a theoretical basis and a spiritual basis for the progressive development of law. Only by forming a good culture of rule of law can we truly realize the modernization of the legal norms at the "artifact" level, provide a broader space for the development of China's economy, and realize the great rejuvenation of the Chinese nation.

\section{Some Rationales for the Construction of the Culture of Rule of Law}

Therefore, in the new era, the culture of rule of law at the conceptual level focuses on the inner recognition, advocacy and belief in rule of law. We need to construct the culture of rule of law and forma culture and legal spirit of believing and honoring law and respecting rights and interests in the whole society. At the same time, improving the quality of citizens will foster and promote the formation of universal freedom, equality, fairness, democracy and rights.

\section{Incorporating modern humanistic spirit}

Integrating the humanistic spirit into the construction of rule of law is a necessary way to construct the culture of rule of law. The so-called humanistic spirit, in short, is the spirit of respecting people, caring for people. This spiritual character is not always there, but a product of market-economic relations based on freedom, democracy, and equal rights. Incorporating the humanistic spirit into all aspects and links of spiritual civilization construction in China will not only greatly enrich the content of China's spiritual civilization construction, but also induce the rational spirit of market entities correctly recognizing and dealing with market economy relations through the influence of spiritual civilization construction [9].

\section{Pay attention to local cultural resources}

Paying full attention to local cultural resources and actively exploring and utilizing the beneficial ingredients is a key link in the construction of a culture of rule of law. In the historical process of their long-term survival and development, each country and nation has created and formed a cultural system that is unique and regards it as its most precious wealth. This part of wealth cannot be exported or imported. In recent years, China has transplanted and introduced advanced western legal technical systems, which resulted in an imbalance between the total supply of legal resources and total demand. Why are the legal and technical systems that we transplant and import, once transplanted and introduced to China, no longer shining, even they are very efficient in Western countries? The profound reason is that it is separated from the local cultural resources on which it works. This cultural resource, as part of the national spirit, cannot be transplanted and introduced. As the accumulation of national wisdom and the spiritual culture of the long-term development of the nation, it cannot be ruled out that China's native cultural resources are still rich in some positive and reasonable elements needed for the present era.

\section{Enrich the communication mechanism of legal culture}

The legal communication culture is one of the basic components of the culture of rule of law. Without the full development of the legal communication culture, there will be no full development of the culture of rule of law.

First of all, enriching the communication mechanism of legal culture must enrich the communication channels. It is an important measure to construct the ethical foundation of the culture of rule of law by changing the legal education method, breaking the narrow discipline restrictions, and exploring and establishing the communication mechanism of law culture education for various disciplines and various media. The construction of the culture of rule of law is a ground-breaking project in the system of rule of law in China. It is not just a matter of law, but a matter of the whole society. This is because modern social life is an organic whole with mutual connection and interaction, and the construction of culture of rule of law involves the social integration mode and behavior regulation mode from the central to the local and even the grassroots communities. It is a way of developing the useful and discarding the useless and renewing of the traditional means of governance. Obviously, it is difficult to work alone by relying on the discipline of law. It is necessary to adapt to the needs of contemporary Chinese practice of rule of law, update the existing concept of legal education, and realize the transformation from single legal education to multidisciplinary and interdisciplinary big law education, and realize the transformation from the legal knowledge education to legal quality education, and establish a reasonable model of legal education combining the "school system" with the "apprenticeship system".

Second, enriching the legal culture communication mechanism need to enrich the scope of communication. The emphasis of the construction of the culture of rule of law is to make it popular with the people by effective dissemination [10]. As one of the important carriers of contemporary legal communication culture, the legal communication activities represented by "Sixth Entry of Law" have a prominent long-term effect on improving the legal quality of all members of society. The socialism culture of rule of law reflects a set of concepts, beliefs, ideals and values, which are inherently required by the socialism rule of law. It is the guideline and principle for guiding and adjusting socialism legislation, enforcement, justice, law-abiding and legal supervision. Through the effective dissemination of the "Legal Advancement" activities, more members of society can understand 
the socialism culture of rule of law put forward on the basis of summing up the practical experience of construction of rule of law and drawing on the achievements of the rule of law in the world, and understand the inherent requirements, basic laws and value orientation of the socialism rule of law. It will promote the socialism culture of rule of law to all levels of social life, expand its coverage and influence, and contribute to the improvement of legal spirit of the whole nation. Of course, we must vigorously explore new and more models of the culture of rule of law. Through the internet+, we should strengthen the propaganda of the culture of rule of law, encourage the literature, art, film and television works focusing on the theme of socialism culture of rule of law, enhance the appeal of the rule of law. To propaganda the culture of the rule of law on the important day of commemoration or special festival, so that people can feel the charm of the culture of the rule of law in leisure.

\section{Conclusion}

The rule of law is the support of the country to achieve the effective governance, and the culture of rule of law is the soul of the construction of the rule of law [11]. Harmonious society is an important historical and epochal proposition put forward by the Party and the state in the process of building and developing the socialism cause with Chinese characteristics. The construction of the culture of rule of law and the connotation of harmonious society are inherently united. The culture of rule of law we want to build not only has the commonality in the development of human culture of rule of law, but also has the nationality and regionality of China. Therefore, the construction of culture of rule of law should adhere to the combination of history and reality, local and extra-territorial, transplantation and innovation. In the new era, we must pay special attention to the promotion and popularization of the culture of rule of law.

\section{References}

1. Yanzhen Q (2006) Legal culture and its cultivation. Theories Monthly 6: 106.

2. Dajin T (2006) Zhejiang's culture of rule of law and its construction path. Zhejiang Social Sciences 2: 90-91.

3. Qinghong Z (2004) Some thoughts on the culture of rule of law and the all-round development of people. Journal of Shaoguan University 4: 50.

4. Yuxi S (2006) The theory and practice of the proposition of "the culture of rule of law in harmonious society". Law 6: 21-22.

5. Zhangrun X (2004) The wisdom of jurists. Beijing: Tsinghua University Press Page No: 108.

6. Deshun L (2018) Shaping the world civilization with the culture of the rule of law. Beijing Daily.

7. Shuang L (2006) National spirit: the cultural support of rule of law. Journal of Nanjing University of Aeronautics and Astronautics 4: 5.

8. Dongdong H (2004) On the cultural basis of rule of law. Hebei Law 1: 206.

9. Xianfu J (2018) The cultural ethical foundation of rule of law and its construction. Legal Science 6: 9.

10. Zhengming K, Wuan S (2018) Focus on strengthening the construction of the culture of the rule of law, People's Daily.

11. Lei Z (2018) The road to the construction of socialism culture of the rule of law. People's Forum. 


\section{II \\ HERALD}

Journal of Anesthesia \& Clinical Care

Journal of Addiction \& Addictive Disorders

Advances in Microbiology Research

Advances in Industrial Biotechnology

Journal of Agronomy \& Agricultural Science

Journal of AIDS Clinical Research \& STDs

Journal of Alcoholism, Drug Abuse \& Substance Dependence

Journal of Allergy Disorders \& Therapy

Journal of Alternative, Complementary \& Integrative Medicine

Journal of Alzheimer's \& Neurodegenerative Diseases

Journal of Angiology \& Vascular Surgery

Journal of Animal Research \& Veterinary Science

Archives of Zoological Studies

Archives of Urology

Journal of Atmospheric \& Earth-Sciences

Journal of Aquaculture \& Fisheries

Journal of Biotech Research \& Biochemistry

Journal of Brain \& Neuroscience Research

Journal of Cancer Biology \& Treatment

Journal of Cardiology: Study \& Research

Journal of Cell Biology \& Cell Metabolism

Journal of Clinical Dermatology \& Therapy

Journal of Clinical Immunology \& Immunotherapy

Journal of Clinical Studies \& Medical Case Reports

Journal of Community Medicine \& Public Health Care

Current Trends: Medical \& Biological Engineering

Journal of Cytology \& Tissue Biology

Journal of Dentistry: Oral Health \& Cosmesis

Journal of Diabetes \& Metabolic Disorders

Journal of Dairy Research \& Technology

Journal of Emergency Medicine Trauma \& Surgical Care

Journal of Environmental Science: Current Research

Journal of Food Science \& Nutrition

Journal of Forensic, Legal \& Investigative Sciences

Journal of Gastroenterology \& Hepatology Research

Journal of Gerontology \& Geriatric Medicine

Journal of Genetics \& Genomic Sciences

Journal of Hematology, Blood Transfusion \& Disorders

Journal of Human Endocrinology

Journal of Hospice \& Palliative Medical Care

Journal of Internal Medicine \& Primary Healthcare

Journal of Infectious \& Non Infectious Diseases

Journal of Light \& Laser: Current Trends

Journal of Modern Chemical Sciences

Journal of Medicine: Study \& Research

Journal of Nanotechnology: Nanomedicine \& Nanobiotechnology

Journal of Neonatology \& Clinical Pediatrics

Journal of Nephrology \& Renal Therapy

Journal of Non Invasive Vascular Investigation

Journal of Nuclear Medicine, Radiology \& Radiation Therapy

Journal of Obesity \& Weight Loss

Journal of Orthopedic Research \& Physiotherapy

Journal of Otolaryngology, Head \& Neck Surgery

Journal of Protein Research \& Bioinformatics

Journal of Pathology Clinical \& Medical Research

Journal of Pharmacology, Pharmaceutics \& Pharmacovigilance

Journal of Physical Medicine, Rehabilitation \& Disabilities

Journal of Plant Science: Current Research

Journal of Psychiatry, Depression \& Anxiety

Journal of Pulmonary Medicine \& Respiratory Research

Journal of Practical \& Professional Nursing

Journal of Reproductive Medicine, Gynaecology \& Obstetrics

Journal of Stem Cells Research, Development \& Therapy

Journal of Surgery: Current Trends \& Innovations

Journal of Toxicology: Current Research

Journal of Translational Science and Research

Trends in Anatomy \& Physiology

Journal of Vaccines Research \& Vaccination

Journal of Virology \& Antivirals

Archives of Surgery and Surgical Education

Sports Medicine and Injury Care Journal

International Journal of Case Reports and Therapeutic Studies

Journal of Ecology Research and Conservation Biology 